\title{
Severe Secondary Hyperparathyroidism in a Hemodialysis Patient: A Case Report from Mongolia
}

\author{
Saruultuvshin Adiya Khurtsbayar Damdinsuren Chuluuntsetseg Dorj \\ Nephrology Center, First Central Hospital of Mongolia, Ulaanbaatar, Mongolia
}

\section{Keywords}

Secondary hyperparathyroidism $\cdot$ Renal bone disease .

Parathyroidectomy Postoperative hypoparathyroidism sive assessment of calcium and phosphorus levels throughout all stages of chronic kidney disease is vital. The postoperative period of PTX in SHPT patients is critical, requiring monitoring to improve management. $\quad 2017 \mathrm{~S}$. Karger AG, Basel

\section{Introduction}

Severe persistent secondary hyperparathyroidism (SHPT) is an indication for parathyroidectomy (PTX) in patients requiring renal replacement therapy [1]. In hemodialysis (HD) patients, PTX is associated with considerable improvement in both biochemical and clinical features of SHPT, with resultant decreased risk of cardiovascular morbidity and mortality as well as all-cause mor-

See www.karger.com/doi/10.1159/000479576 for an infographic on Country Status.

\section{KARGER}

(C) 2017 S. Karger AG, Basel

E-Mail karger@karger.com

www.karger.com/bpu

\footnotetext{
Saruultuvshin Adiya

Nephrology Center, First Central Hospital of Mongolia

Zorig Street 2

Ulaanbaatar 210648 (Mongolia)

E-Mail saruul_tvshn@yahoo.com
} 
Table 1. Laboratory findings during follow-up on MHD, before PTX in 2015

\begin{tabular}{|c|c|c|c|c|c|c|c|}
\hline \multirow[t]{2}{*}{ Laboratory findings } & \multicolumn{6}{|l|}{ Year } & \multirow{2}{*}{$\begin{array}{l}\text { Reference } \\
\text { range }\end{array}$} \\
\hline & 2009 & 2010 & 2011 & 2012 & 2013 & 2014 & \\
\hline Calcium, mmol/L & 2.13 & 2.34 & 2.38 & 2.7 & 2.6 & 2.51 & $2.15-2.55$ \\
\hline Phosphorus, $\mathrm{mmol} / \mathrm{L}$ & 3.7 & 2.9 & 3.31 & 3.2 & 3.1 & 2.84 & $0.87-1.45$ \\
\hline PTH, pg/mL & - & - & 520 & 910 & 1,824 & 2,458 & $15-65$ \\
\hline Hemoglobin, g/dL & 10.8 & 13.2 & 11 & 9.0 & 9.9 & 9.1 & $11.5-16.5$ \\
\hline
\end{tabular}

PTH, parathyroid hormone.

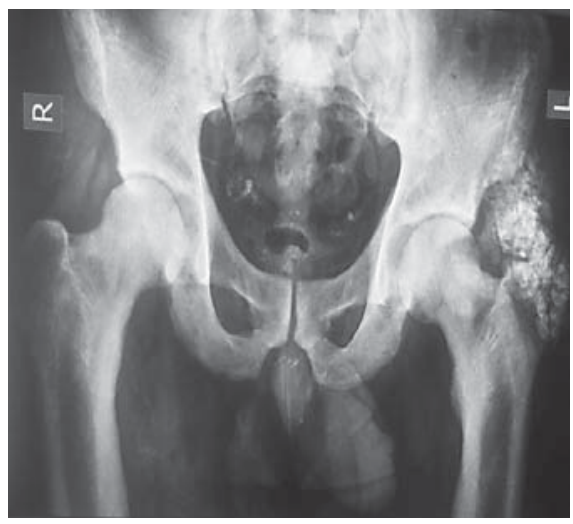

Fig. 1. Imaging findings during medical therapy and 6 months before PTX. X-ray shows soft tissue calcification around the left hip joint.

tality [2]. Here, we report a case of severe SHPT and subsequent PTX in a HD patient with severe postoperative hypocalcemia and discuss the lessons learned from the case.

\section{Case Report}

A 39-year-old Mongolian man with an 11-year history of renal insufficiency secondary to chronic glomerulonephritis presented in 2016 with a history of muscle cramps and periorbital paresthesia for about 1 year during tapering-off of his maintenance oral calcium carbonate dose after PTX. He had no history of smoking or alcohol consumption, with no known allergies and no family history of note. On physical examination, he appeared stable, blood pressure was 130/90 $\mathrm{mm} \mathrm{Hg}$, and heart rate was $84 \mathrm{bpm}$. Body mass index was 24.3 and interdialytic weight gain was $3 \mathrm{~kg}$. There was no pitting edema.

In April 2006, at the age of 28, he was first diagnosed with renal insufficiency. He commenced hemodialysis at our hospital in 2008 ( 8 h weekly for 1 year) and has been on maintenance HD (MHD;
$12 \mathrm{~h}$ weekly) to date. In 2011, he developed pain in both legs, muscle weakness, pruritus, and weight loss lasting the next 5 years. He took oral calcium acetate $700 \mathrm{mg}$ twice daily with meals and calcitriol $1 \mu \mathrm{g}$ daily until 2013. Calcium acetate was then switched to the phosphate binder sevelamer ( $800 \mathrm{mg}$ daily) to control hypercalcemia. Since 2012 he had been anemic despite receiving erythropoietin (EPO), possibly due to EPO resistance, and later in 2015 he developed severe anemia from bleeding gastric ulcer, requiring multiple blood transfusions. Laboratory investigations from 2009 to 2014 revealed mild hypercalcemia, elevated serum phosphorus, and extremely high parathyroid hormone (PTH) levels (Table 1).

In February 2015, he developed painful palpable masses near the left hip joint and both shoulders. Radiography of the left hip joint showed soft tissue calcification on plain X-ray (Fig. 1). Concurrent ultrasound examination showed 2 parathyroid glands measuring $0.6 \times 0.7 \mathrm{~cm}$ and $0.6 \times 0.3 \mathrm{~cm}$ on the right side. He commenced cinacalcet for 3 months based on soft tissue calcification, and PTH was markedly reduced $(2456 \mathrm{pg} / \mathrm{mL}$ to $918 \mathrm{pg} / \mathrm{mL}$ ). However, cinacalcet was discontinued due to non-availability in Mongolia.

Because of failed medical intervention, severe SHPT, and extremely high levels of PTH $(2,040 \mathrm{pg} / \mathrm{mL})$, in August 2015 he underwent definitive treatment with total PTX involving autotransplantation of parathyroid tissue into the right sternocleidomastoid muscle. At surgery, the parathyroid glands were found to be hypertrophied; 2 of the resected glands measured about $2 \mathrm{~cm}$ and the other 2 about $1.5 \mathrm{~cm}$ in length. Twelve hours after PTX, the patient developed severe hypocalcemia with fatigue, dysphagia, myalgia, and paresthesia. He was admitted to the intensive care unit (ICU) and received intravenous (IV) calcium gluconate $20 \mathrm{~g}$ daily (elemental calcium $1.86 \mathrm{~g}$ daily) for 10 days with oral calcium carbonate $5 \mathrm{~g}$ daily and calcitriol $3 \mu \mathrm{g}$ daily) for severe postoperative hypocalcemia. IV calcium replacement therapy was continued for 6 months because he was still quite symptomatic. Figure 2 shows pre- and immediate postoperative laboratory findings.

From around August 2015 to December 2016 during followup, bone pain and itching improved, the subcutaneous masses gradually disappeared, and the calcification resolved (Fig. 3). His general condition improved considerably and serum phosphorus $(1.65 \mathrm{mmol} / \mathrm{L})$ and PTH $(22.3 \mathrm{pg} / \mathrm{mL})$ were within normal reference ranges, and serum calcium $(2.12 \mathrm{mmol} / \mathrm{L})$ decreased slightly.

The latest follow-up was in January 2017, and his current medications are calcium carbonate $5 \mathrm{~g}$ and calcitriol $1 \mu \mathrm{g}$ daily due to occasional episodes of hypocalcemia. He usually also receives IV calcium gluconate. Presently, he has no anemia (hemoglobin 15.5
36

Blood Purif 2017;44(suppl 1):35-40 DOI: $10.1159 / 000479616$
Adiya/Damdinsuren/Dorj 
Fig. 2. Laboratory findings before and immediately after PTX. Preop period, 22 weeks before PTX.

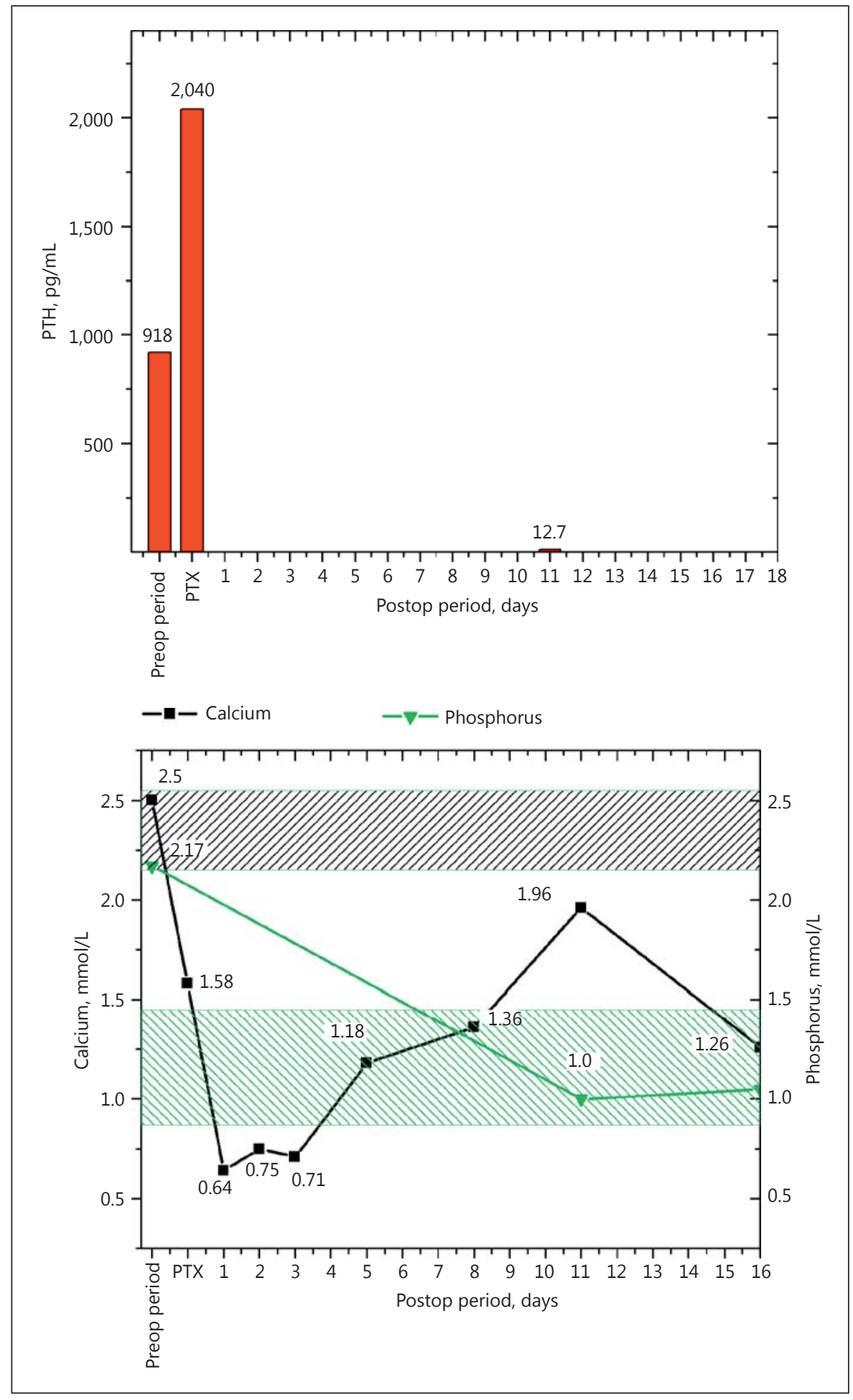

Blood Purif 2017;44(suppl 1):35-40 DOI: $10.1159 / 000479616$ 


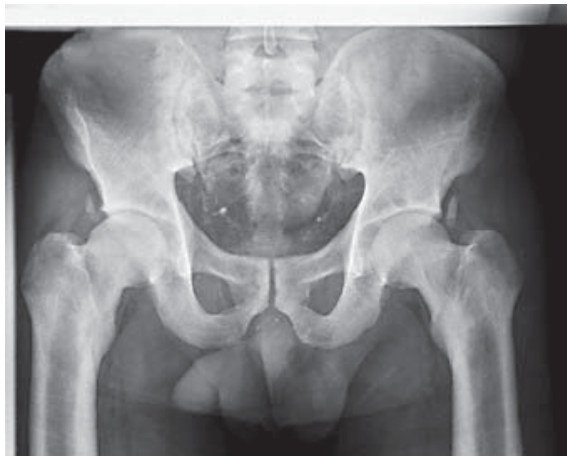

Fig. 3. X-ray at 17 months after PTX shows resolution of previous soft tissue calcification around the left hip joint (January 2017, latest follow-up).

g/dL) despite no longer receiving EPO therapy. Post-PTX laboratory investigations show alkaline phosphatase (ALP) has returned to normal (from 1386.1 to $208.8 \mathrm{U} / \mathrm{L}$, reference range 64-306 U/L) (Fig. 4). Our final diagnosis is SHPT in an HD patient requiring surgical intervention with PTX after failed medical treatment.

\section{Discussion}

Disorders of calcium and phosphorus metabolism are common in patients with chronic renal failure (CRF), often presenting as hypocalcemia, hyperphosphatemia, and renal bone disease and vascular calcifications with associated increased risk of bone fracture and cardiovascular events, respectively. Several treatment modalities for SHPT exist. Control of hyperphosphatemia can be achieved by dietary phosphate restriction, use of phosphate binders, active vitamin $\mathrm{D}$, and intensified dialysis. Calcium-containing phosphate binders and vitamin $\mathrm{D}$ sterols are widely recommended for treating SHPT but may cause hypercalcemia and hyperphosphatemia, further increasing the risk of soft tissue and vascular calcification. Non-calcium-containing phosphate binders, sevelamer, new vitamin $\mathrm{D}$ analogues, and calcimimetic agents provide safer and effective control of SHPT, with reduced risk of soft tissue and vascular calcification [3-5]. The calcimimetic cincalcet $\mathrm{HCl}$ acts to increase sensitivity of the calciumsensing receptor to calcium, thereby reducing PTH secretion [6].

Medical therapy is not always successful in the management of SHPT, and PTX is needed in a considerable number of patients on MHD or who are renal graft re- cipients [7]. Following PTX, hypocalcemia may be induced by either postoperative hypoparathyroidism or hungry bone syndrome and each must be differentiated from the other. Postoperative hypoparathyroidism is caused by injury to the parathyroid glands or their blood supply and in advertent resection of parathyroid tissue. Hungry bone syndrome is a rare condition that induces rapid profound hypocalcaemia with hypophosphatemia and hypomagnesaemia, and is exacerbated by suppressed PTH in postoperative patients with severe SHPT and high preoperative bone turnover. Such cases require oral and IV calcium replacement and calcitriol $[8,9]$.

Contributory factors to developing SHPT in the present case include late diagnosis of the primary renal disorder. Appropriate treatment was delayed and the patient developed severe SHPT despite medical treatment with phosphate binders, calcitriol, and calcimimetics. Another factor is insufficient dialysis for 1 year after diagnosis. Calcium and calcitriol maintenance therapy may also have aggravated the soft tissue calcification. Cinacalcet was effective and reduced serum PTH but not to the target level, possibly due to late administration of calcimimetics in this patient with severe persistent SHPT. Moreover, long-term administration could not be maintained in this patient because the drug is currently unavailable in Mongolia.

The resected parathyroid glands were hypertrophied and the patient developed postoperative complications due to severe hypocalcemia, eventually requiring IV and oral calcium supplementation for 6 months. In the past 1 year however, the main complaints and soft tissue calcification have resolved and serum calcium, phosphorus, and PTH levels have decreased to normal values. However, the patient sometimes presents with episodic hypocalcemia, possibly due to postoperative hypoparathyroidism, and is currently taking calcium carbonate and calcitriol.

Regular comprehensive assessment of calcium and phosphorus levels throughout all stages of CKD is requisite. Medical management of SHPT is beneficial in HD patients. Failed medical treatment of SHPT necessitates surgical intervention with PTX, and the critical postoperative period following PTX requires close monitoring to improve management.

\section{Acknowledgements}

The authors thank Florence Orim, MD, PhD, and Caryn Jones of ThinkSCIENCE, Japan, for medical writing support. 


\begin{tabular}{|c|c|}
\hline Patient Assessment & \\
\hline December 2016 & 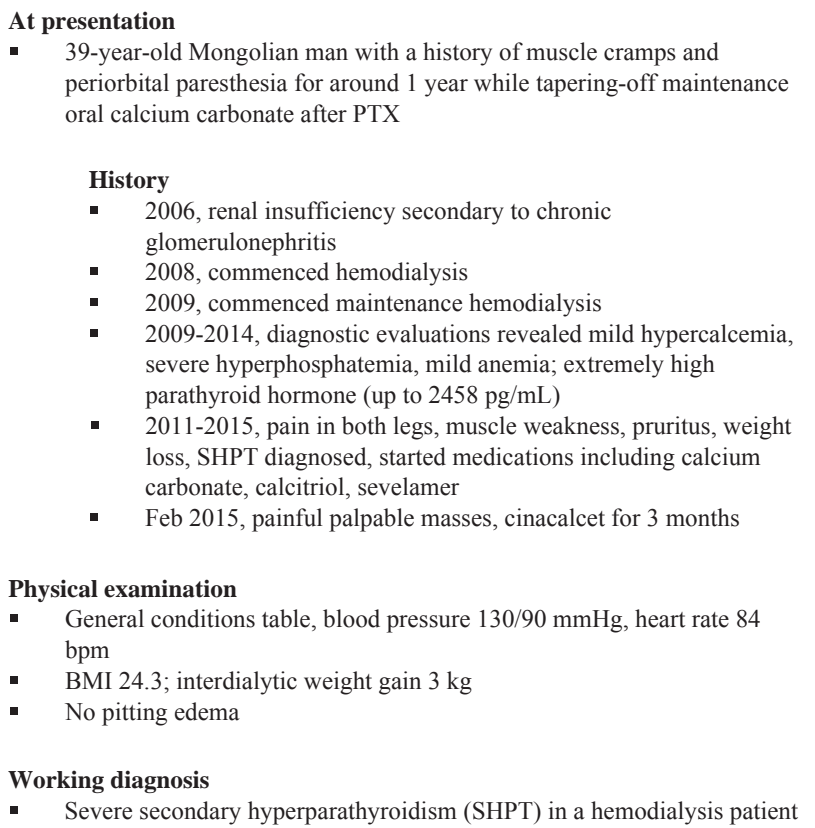 \\
\hline \multicolumn{2}{|c|}{ Therapeutic Interventions and Outcome } \\
\hline & $\begin{array}{l}\text { Therapeutic interventions } \\
\text { - August } 2015 \text {, total PTX with autotransplantation of parathyroid tissue } \\
\text { into right sternocleidomastoid } \\
\text { - } 12 \mathrm{~h} \text { postoperatively, developed severe hypocalcemia } \\
\text { Intensive care management for severe postoperative hypocalcemia } \\
\text { - } \quad \text { IV calcium gluconate } 20 \mathrm{~g} \text { for } 10 \text { days }+ \text { oral calcium carbonate } 5 \mathrm{~g} \text { daily } \\
\text { - Calcitriol } 3 \mu \mathrm{g} \text { daily }\end{array}$ \\
\hline & $\begin{array}{l}\text { Outcome } \\
\text { August } 2015 \text {-December } 2016 \text {, general condition much improved } \\
\text { - } \quad \text { Bone pain and itching improved } \\
\text { - } \quad \text { Subcutaneous masses and calcification resolved (Fig. } 3) \\
\text { range } \\
\text { - Serum calcium }(2.12 \mathrm{mmol} / \mathrm{L}) \text { decreased slightly } \\
\text { - Occasional hypocalcemic episodes } \\
\text { Current medications: calcium carbonate } 5 \mathrm{~g} \text {, calcitriol } 1 \mu \mathrm{g} \text { daily, and IV } \\
\text { calcium gluconate } \\
\text { No anemia }(\mathrm{Hb} 15.5 \mathrm{~g} / \mathrm{dL}) \text { despite no longer receiving EPO therapy }\end{array}$ \\
\hline \multicolumn{2}{|c|}{ Follow-up Assessment of Outcomes } \\
\hline January 2017 & $\begin{array}{l}\text { Latest follow-up visit } \\
\text { - } \quad \text { PTH and ALP now normal } \\
\text { - } \quad \text { Medications, calcium carbonate } 5 \mathrm{~g} \text {, calcitriol } 1 \mu \mathrm{g} \text { daily, IV calcium } \\
\text { gluconate for occasional hypocalcemic episodes with muscle cramps } \\
\text { - } \quad \text { Stopped EPO but no anemia } \\
\text { Final diagnosis } \\
\text { - SHPT in an HD patient requiring surgical intervention with PTX after } \\
\quad \text { failed medical treatment }\end{array}$ \\
\hline
\end{tabular}

Fig. 4. Timeline of the patient's outcome.

Severe Secondary Hyperparathyroidism in a Hemodialysis Patient
Blood Purif 2017;44(suppl 1):35-40 DOI: $10.1159 / 000479616$ 


\section{Statement of Ethics}

The patient provided written informed consent for his case to be published.

\section{Disclosure Statement}

Writing support, for educational purposes, was funded by $\mathrm{Ni}$ pro Corporation, Japan. Nipro Corporation had no role in the selection of presented case, the collection and analysis of the data, or in the preparation of the manuscript.

\section{References}

1 Francisco LM, Fresnedo GF, Rodrigo E, Pinera C, Amado JA, Arias M: Parathyroidectomy in dialysis patients. Kidney International 2002;61(suppl 80):S161-S166.

2 Komaba $\mathrm{H}$, Taniguchi M, Wada A, Iseki K, Tsubakihara Y,Fukagawa M: Parathyroidectomy and survival among Japanese hemodialysis patients with secondary hyperparathyroidism. Kidney International 2015;88:350-359.

3 Goodman WG:Medical management of secondary hyperparathyroidism in chronic renal failure. Nephrol Dial Transplant 2003; 18(suppl 3):iii2-iii8.

4 Daugirdas JT, Chertow GM, Larive B, Pierratos A, Greene T, Ayus JC, Kendrick CA, James SH, Miller BW, Schulman G, Salusky IB, Kliger AS, and Frequent Hemodialysis Network (FHN) Trial Group: Effects of frequent hemodialysis on measures of CKD mineral and bone disorder. J Am Soc Nephrol 2012; 23:727-738.

5 Salusky IB, Goodman WG, Sahney S, Gales B, Perilloux A, Wang HJ, Elashoff RM, Jüppner $\mathrm{H}$ : Sevelamer controls parathyroid hormoneinduced bone disease as efficiently as calcium carbonate without increasing serum calcium levels during therapy with active vitamin D sterols. J Am Soc Nephrol 2005;16:25012508.

6 Lindberg JS, Culleton B, Wong G, Borah MF, Clark RV, Shapiro WB, Roger SD, Husserl FE, Kassen PS, Guo MD, Albizem MB, Coburn JW: Cincalcet HCL, an oral calcimimetic agent for the treatment of secondary hyperparathyroidism in hemodialysis and peritoneal dialysis: a randomized, double-blind, multicenter study. J Am Soc Nephrol 2005; 16 : 800-807.

7 Malberti F, Marcelli D, Conte M, Limido A, Spotti D, Locatelli F: Parathyroidectomy in patients on renal replacement therapy: An epidemiologic study. J Am Soc Nephrol 2005; 16 : 800-807.

8 Witteveen JE, Thiel S van, Romijin JA, Hamdy NAT: Hungry bone syndrome: still a challenge in the post-operative management of primary hyperparathyroidism: a systemic review of the literature. European Journal of Endocrinology 2013;168:R45-R53.

9 Stack BC, Bimston DN, Bodenner DL, Brett EM, Dralle H,Orloff LA, Pallota J, Snyder SK, Wong RJ, Randolph GW: Postoperative hypoparathyroidism-definitions and management. Endocr Pract 2015;21:674-685. 